Article

\title{
The Challenge of Achieving a High Density of Fe-Based Active Sites in a Highly Graphitic Carbon Matrix
}

\author{
Jingkun Li ${ }^{1, *}$, Qingying Jia ${ }^{2}$, Sanjeev Mukerjee ${ }^{2}$, Moulay-Tahar Sougrati ${ }^{1}$, Goran Drazic ${ }^{3}{ }^{(0)}$, \\ Andrea Zitolo ${ }^{4}$ and Frédéric Jaouen ${ }^{1, *}$ \\ 1 Institut Charles Gerhardt Montpellier, UMR 5253, CNRS, Université Montpellier, ENSCM, Place Eugène \\ Bataillon, CEDEX 5, 34095 Montpellier, France; moulay-tahar.sougrati@umontpellier.fr \\ 2 Department of Chemistry and Chemical Biology, Northeastern University, Boston, MA 02115, USA; \\ Q.Jia@northeastern.edu (Q.J.); s.mukerjee@northeastern.edu (S.M.) \\ 3 Department of Materials Chemistry, National Institute of Chemistry, 1000 Ljubljana, Slovenia; \\ goran.drazic@ki.si \\ 4 Synchrotron SOLEIL, L'orme des Merisiers, BP 48 Saint Aubin, 91192 Gif-sur-Yvette, France; \\ andrea.zitolo@synchrotron-soleil.fr \\ * Correspondence: jingkun.li@umontpellier.fr (J.L.); frederic.jaouen@umontpellier.fr (F.J.)
}

Received: 11 December 2018; Accepted: 11 January 2019; Published: 2 February 2019

\begin{abstract}
As one of the most promising platinum group metal-free (PGM-free) catalysts for oxygen reduction reaction (ORR), $\mathrm{Fe}-\mathrm{N}-\mathrm{C}$ catalysts with a high density of $\mathrm{FeN}_{\mathrm{x}}$ moieties integrated in a highly graphitic carbon matrix with a proper porous structure have attracted extensive attention to combine the high activity, high stability and high accessibility of active sites. Herein, we investigated a $\mathrm{ZnCl}_{2} / \mathrm{NaCl}$ eutectic salts-assisted ionothermal carbonization method (ICM) to synthesize Fe-N-C catalysts with tailored porous structure, high specific surface area and a high degree of graphitization. However, it was found to be challenging to anchor a high density of $\mathrm{FeN}_{\mathrm{x}}$ sites onto highly graphitized carbon. Iron precursors with preexisting $\mathrm{Fe}-\mathrm{N}$ coordination were required to form $\mathrm{FeN} \mathrm{N}_{\mathrm{x}}$ sites in the nitrogen-doped carbon with a high degree of graphitization, while individual Fe and $\mathrm{N}$ precursors led to a Fe-N-C catalyst with poor-ORR activity. This provides valuable insights into the synthesis-structure relationship. Moreover, the $\mathrm{FeN}_{\mathrm{x}}$ moieties were identified as the major active sites in acidic conditions, while both $\mathrm{FeN}_{\mathrm{x}}$ sites and $\mathrm{Fe}_{2} \mathrm{O}_{3}$ were found to be active in alkaline medium.
\end{abstract}

Keywords: oxygen reduction reaction; Fe-N-C; active site; graphitic carbon

\section{Introduction}

The oxygen reduction reaction (ORR) is a cornerstone of various electrochemical energy storage and conversion devices [1-3], including metal-air batteries and fuel cells. Proton exchange membrane fuel cell (PEMFC) is a key technology to provide clean and sustainable energy conversion with potential applications in portable electronics, electric vehicles, and residential power generation. Recently, hydroxide exchange membrane fuel cells (HEMFCs) have attracted significant attention due to the tremendous progress in developing highly conductive and stable membranes and ionomers against hydroxide attack [4]. However, the significant amount of Pt needed at the cathode side to accelerate the sluggish ORR kinetics remains a long-standing impediment for the widespread commercialization of PEMFCs and HEMFCs [4,5]. Thus, extensive efforts have been devoted to reducing or eliminating the use of precious metals at the cathode side in the past decades [6-10]. $\mathrm{Fe}(\mathrm{Co})-\mathrm{N}-\mathrm{C}$ catalysts represent the most promising precious metal-free (PGM-free) catalysts, with their ORR activity approaching or 
even surpassing that of commercial $\mathrm{Pt} / \mathrm{C}$ in acidic and alkaline media [11-15], bringing us closer to empowering precious metal-free cathodes in practical $\mathrm{H}_{2}$ /air PEMFCs and HEMFCs.

$\mathrm{Fe}(\mathrm{Co})-\mathrm{N}-\mathrm{C}$ catalysts are generally prepared via a high temperature pyrolysis of various metal, carbon, and nitrogen precursors, often leading to the coexistence of $\mathrm{MN}_{\mathrm{x}} \mathrm{C}_{\mathrm{y}}$ moieties and metallic aggregates (carbides/nitrides/oxides) [16]. After decades of efforts to understand the origin of the ORR activity of pyrolyzed $\mathrm{Fe}(\mathrm{Co})-\mathrm{N}-\mathrm{C}$ catalysts, a consensus has been reached that $\mathrm{Fe}(\mathrm{Co}) \mathrm{N}_{\mathrm{x}}$ sites with the metal center coordinated with several nitrogen atoms located in the equatorial plane exhibit the highest intrinsic ORR activity, when normalized per atom of iron/cobalt [11,12,17-19]. However, the exact structure of such sites (e.g., pyrrolic vs. pyridinic nitrogen ligating the metal cation, edge vs. in-plane location of Metal- $\mathrm{N}_{\mathrm{x}}$ moieties) [16], as well as the role of the carbon matrix in tuning the ORR activity and/or stability (e.g., basicity [11], graphitic or amorphous ordering [20]) is still under debate. In addition to the local structure of $\mathrm{Fe}(\mathrm{Co}) \mathrm{N}_{\mathrm{x}}$ moieties, the porous structure of the carbon matrix in $\mathrm{Fe}(\mathrm{Co})-\mathrm{N}-\mathrm{C}$ catalysts plays a crucial role for their ORR activities. Micropores are generally believed to host $\mathrm{Fe}(\mathrm{Co}) \mathrm{N}_{\mathrm{x}}$ moieties [17,21], while the meso/macropores are proposed to assist the mass transport of ORR-related species toward and away from active sites [22,23]. Thus, the preparation of $\mathrm{Fe}(\mathrm{Co})-\mathrm{N}-\mathrm{C}$ catalysts with a high density of Metal- $\mathrm{N}_{\mathrm{x}}$ moieties integrated in a highly-graphitic carbon matrix integrating both micropores and larger pores (meso or macropores) seems attractive to combine high activity, high stability and high accessibility of active sites.

The ionothermal carbonization method (ICM) is an efficient strategy to synthesize nitrogen-doped carbons with tailored porous structure and ultra-high specific surface areas (>2000 $\mathrm{m}^{2} / \mathrm{g}$ ) [24-27]. Particularly, the addition of eutectic salts $\mathrm{ZnCl}_{2} / \mathrm{AMCl}$ ( $\mathrm{AM}=\mathrm{Li}, \mathrm{Na}$, or $\mathrm{K}$ ) to organic $\mathrm{C}$ and $\mathrm{N}$ precursors was demonstrated to be effective to modulate the porous structures of nitrogen-doped carbons prepared via pyrolysis [28]. $\mathrm{ZnCl}_{2}$ with a low melting point acted as a porogen due to its early evaporation during pyrolysis [29]. On the other hand, $\mathrm{AMCl}$ salt with high melting point remained in the carbon matrix during the entire pyrolysis process, being removed only after pyrolysis via acid washing, generating a specific porous structure through a templating effect [29]. Moreover, the molten state of eutectic salt in a broad temperature range creates a "semiclosed system" with ionic-liquid-confined space, which reduces the loss of nitrogen and carbon during pyrolysis, and thus promotes the yield and nitrogen doping efficiency [29].

In this study, we therefore investigated a eutectic-salt $\left(\mathrm{ZnCl}_{2} / \mathrm{NaCl}\right)$-assisted ICM to synthesize $\mathrm{Fe}-\mathrm{N}-\mathrm{C}$ catalysts (labelled FeNC-ICM hereafter) with high amounts of meso/macropores and high graphitization, and revealed the critical role of the nature of the iron precursor to obtain a high ORR activity for this approach. Individual iron and nitrogen precursors (e.g., Fe acetate and phenanthroline) were previously demonstrated to be efficiently transformed during pyrolysis into $\mathrm{FeN}_{\mathrm{x}}$ moieties in highly disordered N-C matrix (e.g., ZIF-8 derived Fe-N-C catalysts) [11-14,17]. However, the use of individual iron and nitrogen precursors were shown in this study to lead to poor ORR activity. Iron precursors with preexisting Fe-N coordination (Fe-phthalocyanine or Fe-phenanthroline complex) were required to obtain high ORR activity. Advanced material characterization showed that the fraction of Fe present as $\mathrm{FeN}_{\mathrm{x}}$ moieties and the absolute site density of $\mathrm{FeN}_{\mathrm{x}}$ moieties were low in the presently investigated materials, and that the $\mathrm{N}$-doped carbon matrix was highly graphitic. A significant fraction of Fe was also present in the form of iron carbide and nanosized Fe oxide, suggesting it is more difficult to integrate a high density of $\mathrm{FeN}_{\mathrm{x}}$ moieties in a highly graphitic carbon matrix than in an amorphous one. These results provide valuable insights into the synthesis-structure relationships of pyrolyzed $\mathrm{Fe}-\mathrm{N}-\mathrm{C}$ catalysts. Moreover, the $\mathrm{FeN}_{\mathrm{x}}$ moieties were identified as the major active sites for the ORR in acidic medium, while both $\mathrm{FeN}_{\mathrm{x}}$ moieties and nanosized iron oxides were found to contribute to the ORR activity in alkaline medium. 


\section{Results}

\subsection{ORR Activity}

The FeNC-ICM catalysts were prepared via pyrolysis at $900{ }^{\circ} \mathrm{C}$ in inert atmosphere of a catalyst precursor including a dual carbon and nitrogen source (adenine), an iron source and the $\mathrm{ZnCl}_{2} / \mathrm{NaCl}$ eutectic salt. Three iron precursors were studied, namely iron(II) phthalocyanine (FePc), 1,10-phenanthroline iron(II) perchlorate $\left(\mathrm{FePhen}_{3}\right)$ and iron(II) acetate $\left(\mathrm{FeAc}_{2}\right)$, keeping all other synthesis parameters unchanged. The catalyst precursors were prepared with a fixed mass ratio of adenine/salts of 1/10, while the mass of each Fe precursor was adjusted to reach $4 \mathrm{wt} . \%$ Fe relative to the sum of (nitrogen + carbon mass) in the catalyst precursors. The detailed synthesis protocol is given in Materials and Methods. When using $\mathrm{FeAc}_{2}$ as Fe precursor, the amount of 1,10-phenanthroline necessary to reach a molar ratio Phen/Fe of 3 was also added, in order to ensure all three precursors possessed similar nitrogen contents. The catalysts obtained after pyrolysis and water-wash (to remove $\mathrm{NaCl}$ ) are labelled as ICM-FePc, ICM-FePhen 3 and ICM-FeAc 2 , the second part of the label identifying the iron precursor used.

The ORR activity of FeNC-ICM catalysts was evaluated with a rotating disk electrode (RDE) setup in both acidic and alkaline media. First, the effect of the nature of the iron precursor in the ICM approach on the ORR activity in acidic electrolyte was studied (Figure 1a). The ICM-FeAc 2 catalyst showed a low onset potential for ORR in $0.1 \mathrm{M} \mathrm{HClO}_{4}$ and poorly-defined diffusion-limited current density. In contrast, the ICM-FePc and ICM-FePhen 3 catalysts exhibited a half-wave potential $\left(E_{1 / 2}\right)$ of 0.75 and $0.77 \mathrm{~V}$ vs. a reversible hydrogen electrode (RHE), respectively. They also showed a well-defined redox peak at $\sim 0.73 \mathrm{~V}$ vs. RHE in cyclic voltammograms $(\mathrm{CVs})$ recorded in $\mathrm{N}_{2}$-saturated acidic medium, while no redox peak was observed for ICM-FeAc 2 (Figure 1b). This redox peak has previously been attributed to the $\mathrm{Fe}^{2+/ 3+}-\mathrm{N}_{4}$ redox transition in pyrolyzed $\mathrm{Fe}-\mathrm{N}-\mathrm{C}$ materials $[17,30]$. This suggests that, with the present synthesis method, the $\mathrm{FeN}_{\mathrm{x}}$ moieties could only form at high temperature when using Fe precursors with pre-existing $\mathrm{Fe}-\mathrm{N}_{4}$ or $\mathrm{Fe}-\mathrm{N}_{6}$ coordinations, while the $\mathrm{FeAc}_{2}$ in the presence of Phen did probably not form the Fe(phen) ${ }_{3}$ complex during the dry ball-milling before pyrolysis, and could apparently not form $\mathrm{FeN}_{\mathrm{x}}$ moieties during the pyrolysis either. This result is different from what has been observed for other synthesis approaches, where separate $\mathrm{FeAc}_{2}$ and 1,10-phenanthroline precursors, mixed with ZIF-8 as a sacrificial carbon precursor, entirely converted into $\mathrm{FeN}_{\mathrm{x}}$ moieties in the $\mathrm{ZIF}-8$ derived $\mathrm{Fe}-\mathrm{N}-\mathrm{C}[11-14,17]$. Figure $1 \mathrm{~b}$ further showed that the $\mathrm{CV}$ of ICM-FeAc 2 was tilted and strongly deviated from a square signal, typical for samples with low electronic conductivity. This suggests that the nature of the iron precursor not only affected the formation of $\mathrm{FeN}_{\mathrm{x}}$ moieties, but also changed the nature of the carbon matrix obtained during pyrolysis. As will be shown later in this study, the situation is however complex here, with the presence of three different Fe-based species in ICM-FePhen ${ }_{3}$, and its redox assignment is further discussed after advanced spectroscopic characterization. 

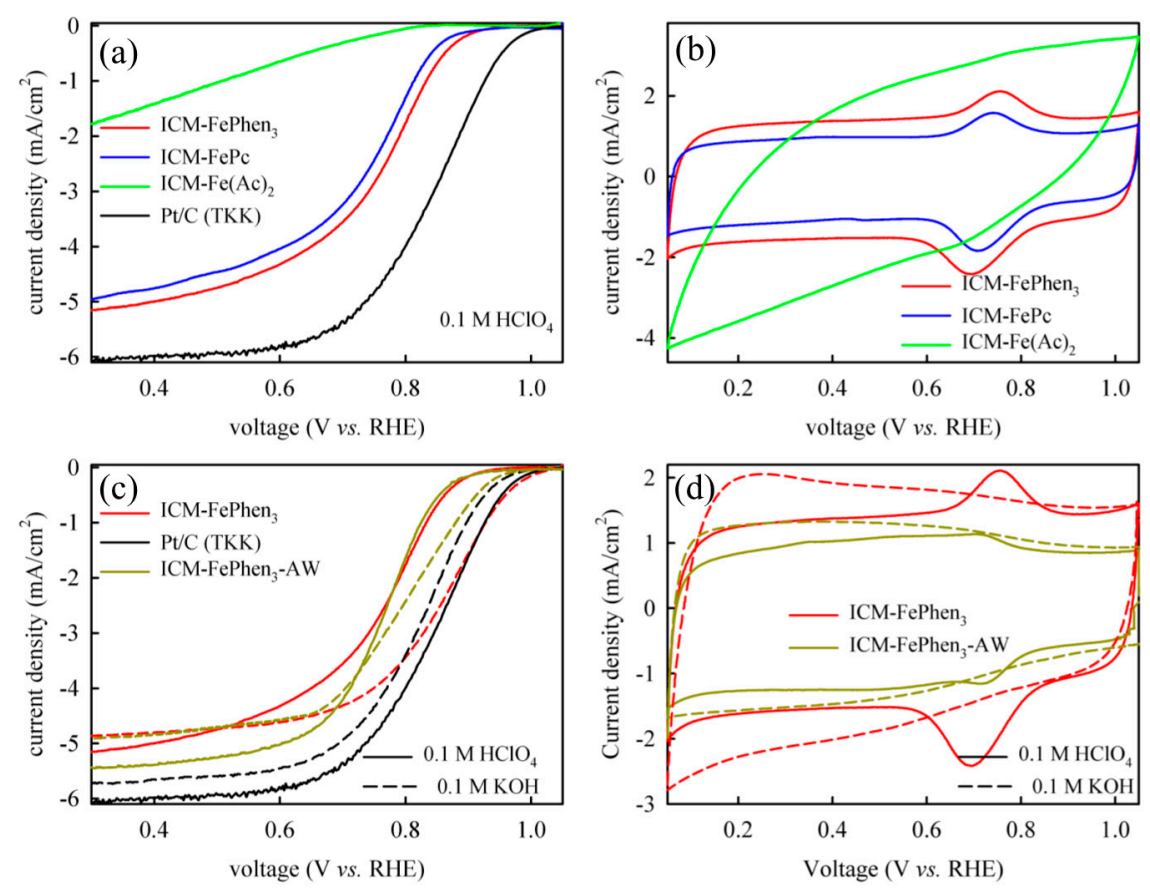

Figure 1. Electrochemical evaluation of ionothermal carbonization method (ICM)-derived Fe-N-C catalysts prepared from different iron precursors. (a) Oxygen reduction reaction (ORR) polarization curves measured in $\mathrm{O}_{2}$-saturated $0.1 \mathrm{M} \mathrm{HClO}_{4}$ with a scan rate of $20 \mathrm{mV} / \mathrm{s}$ at $1600 \mathrm{rpm}$. (b) Cyclic voltammograms (CVs) measured in $\mathrm{N}_{2}$-saturated $0.1 \mathrm{M} \mathrm{HClO}_{4}$ with a scan rate of $20 \mathrm{mV} / \mathrm{s}$. (c) ORR polarization curves of ICM-FePhen ${ }_{3}$ catalyst before and after an acid wash (AW), measured in $\mathrm{O}_{2}$-saturated $0.1 \mathrm{M} \mathrm{HClO}_{4}$ or $0.1 \mathrm{M} \mathrm{KOH}$ with a scan rate of $20 \mathrm{mV} / \mathrm{s}$ at $1600 \mathrm{rpm}$. (d) $\mathrm{CVs}$ measured in $\mathrm{N}_{2}$-saturated $0.1 \mathrm{M} \mathrm{HClO}_{4}$ or $0.1 \mathrm{M} \mathrm{KOH}$ with a scan rate of $20 \mathrm{mV} / \mathrm{s}$. Results obtained with a commercial Pt/C catalyst (Tanaka Kikinzoku Kogyo (TKK, Japan), 46.7 wt.\% Pt, anodic scan) are presented as a reference. The catalyst loading for Fe-N-C is $800 \mu \mathrm{g} / \mathrm{cm}^{2}$. The Pt loading is $10 \mu \mathrm{g}_{\mathrm{Pt}} / \mathrm{cm}^{2}$.

The most active ORR-catalyst in acid medium, ICM-FePhen 3 , was further characterized with X-ray diffraction (XRD) and Raman spectroscopy in order to identify the structure of the carbon matrix. Compared to the broad peaks $\left(24^{\circ}\right.$ and $\left.43^{\circ}\right)$ associated with amorphous carbon in the XRD patterns of a ZIF-8 derived $\mathrm{Fe}-\mathrm{N}-\mathrm{C}$ catalyst (labelled $\mathrm{Fe}_{0.5} \mathrm{NC}$, used here as reference $\mathrm{Fe}-\mathrm{N}-\mathrm{C}$ catalyst from our laboratory that was demonstrated to comprise only $\mathrm{FeN}_{\mathrm{x}}$ moieties [3]), ICM-FePhen 3 exhibited narrower graphite-related peaks in XRD (peaks at $26^{\circ}, 43^{\circ}$ and $45^{\circ}$, Figure 2a). The first-order Raman spectrum of ICM-FePhen 3 showed two peaks: the $\mathrm{G}$ band at $\sim 1590 \mathrm{~cm}^{-1}$ and the disorder-induced $\mathrm{D}$ band at $\sim 1360 \mathrm{~cm}^{-1}$ (Figure $2 \mathrm{~b}$ ). In the second-order Raman spectrum, three less intense peaks were observed, namely the $G^{\prime}(2 \mathrm{D})$ band at $\sim 2710 \mathrm{~cm}^{-1}$ attributed to the D-band overtone, the peak at $\sim 2918 \mathrm{~cm}^{-1}$ due to a combination of D and G band, and the peak at $\sim 3240 \mathrm{~cm}^{-1}$ ascribed to the G-band overtone (Figure 2b) [31]. ICM-FePhen 3 showed a lower $\mathrm{I}_{\mathrm{D}} / \mathrm{I}_{\mathrm{G}}$ ratio $(0.67 \mathrm{vs.} 0.84)$ and a much more intense peak at $2710 \mathrm{~cm}^{-1}$ (widely observed in graphite and graphene) [32] compared to $\mathrm{Fe}_{0.5} \mathrm{NC}$ (Figure 2b), further revealing its higher degree of graphitization. Graphitic carbon is believed to have improved corrosion resistance relative to amorphous carbon, which could result in improved stability of Fe-N-C catalysts in PEMFCs or HEMFCs [33]. However, a synthetic contradiction between the desire for a high density of $\mathrm{FeN}_{\mathrm{x}}$ sites and a high degree of graphitization of carbon might occur, as discussed later. 

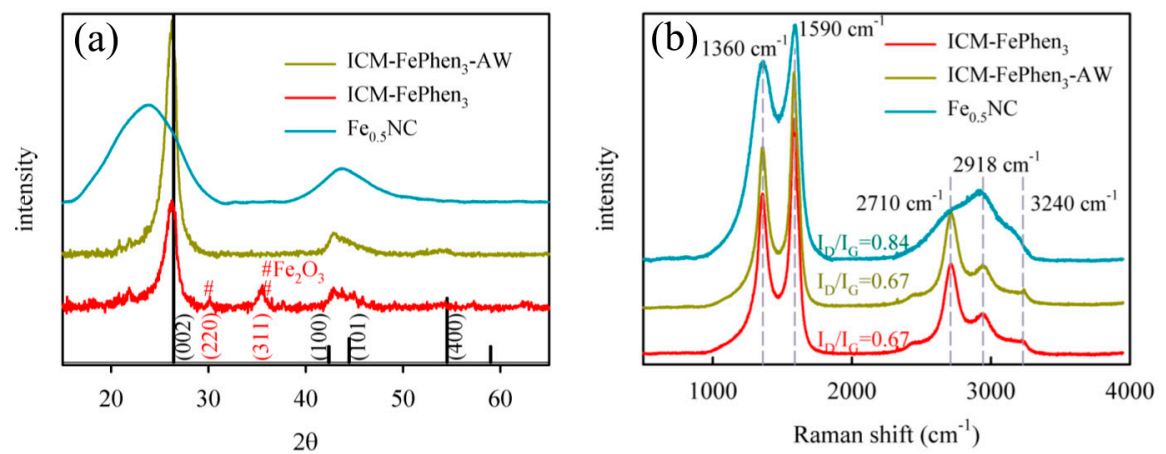

Figure 2. (a) X-ray diffraction (XRD) patterns, and (b) Raman spectra of ICM-derived Fe-N-C catalysts. The XRD and Raman spectra of $\mathrm{Fe}_{0.5} \mathrm{NC}$ (a ZIF-8 derived Fe-N-C pyrolyzed material [11]) are also presented as references for a material that comprises only $\mathrm{FeN}_{\mathrm{x}}$ moieties integrated in amorphous carbon.

Then the ORR activity of ICM-FePhen 3 was evaluated in $0.1 \mathrm{M} \mathrm{HClO}_{4}$ and $0.1 \mathrm{M} \mathrm{KOH}$, as well as after acid wash (denoted as ICM-FePhen 3 -AW) (Figure 1c). The acid wash did not affect the ORR activity of ICM-FePhen ${ }_{3}$ in acidic medium (same on-set potential and half-wave potential as ICM-FePhen 3 ), but resulted in a higher diffusion-limited current density, possibly due to the removal of poorly-active Fe species favoring the 2-electron reduction of ORR to $\mathrm{H}_{2} \mathrm{O}_{2}$. Moreover, ICM-FePhen 3 -AW exhibited a redox (attributed to $\mathrm{Fe}^{2+/ 3+} \mathrm{N}_{4}$ ) at similar potentials (but much lower intensity) than observed for ICM-FePhen ${ }_{3}$, suggesting that $\mathrm{FeN}_{\mathrm{x}}$ moieties survived the acid wash, and probably worked as the major active sites for ORR in acid (Figure 1d). In alkaline medium, $\mathrm{ICM}^{-F e P h e n}{ }_{3}$ and ICM-FePhen 3 -AW showed however different ORR activities, contrasting with the case in acidic medium. ICM-FePhen ${ }_{3}-\mathrm{AW}$ had an $\mathrm{E}_{1 / 2}$ value negatively shifted by $60 \mathrm{mV}$ vs. ICM-FePhen ${ }_{3}$. These two observations strongly suggest that the acid-wash removed some Fe species that are ORR-inactive in acidic medium but ORR-active in alkaline medium. The iron speciation is reported and discussed further below. For the most active sample, ICM-FePhen 3 , its $\mathrm{E}_{1 / 2}$ value at a catalyst loading of $800 \mu \mathrm{g}_{\mathrm{FeNC}} / \mathrm{cm}^{2}$ in alkali was $0.86 \mathrm{~V}$ vs. RHE, surpassing that of the commercial $\mathrm{Pt} / \mathrm{C}$ (TKK, $10 \mu \mathrm{g}_{\mathrm{Pt}} / \mathrm{cm}^{2}$ ). This is among the best ORR activities reported for Fe-N-C catalysts in alkali [34-37].

\subsection{Iron Speciation}

In order to identify the Fe species present in ICM-FePhen 3 and ICM-FePhen $3-\mathrm{AW}, \mathrm{XRD},{ }^{57} \mathrm{Fe}$ Mössbauer spectroscopy, and X-ray absorption spectroscopy (XAS) measurements were performed. The presence of $\mathrm{Fe}_{2} \mathrm{O}_{3}$ was detected by XRD in ICM-FePhen 3 (main peak at ca $36^{\circ}$ and secondary peaks at ca $30^{\circ}$, JCPDS \#39-1346), but not detected in ICM-FePhen 3 -AW (Figure 2a). With room-temperature ${ }^{57} \mathrm{Fe}$ Mössbauer spectroscopy, four major spectral components were detected in ICM-FePhen 3 (Figure 3a and Table 1): a sextet assigned to iron carbide $\left(\mathrm{Fe}_{3} \mathrm{C}, 30 \%\right)$, two sextets assigned to iron oxide $\left(\varepsilon-\mathrm{Fe}_{2} \mathrm{O}_{3}, 12 \%\right)$ [38], a broad singlet (12\%) and a doublet (46\%). The assignment of the singlet will be discussed later. The Mössbauer parameters of that doublet (Table 1) allow the following straightforward but ambiguous assignment: i) either the $\mathrm{D} 1$ component typical for low-spin ferrous $\mathrm{FeN}_{4}$ moiety in pyrolyzed Fe-N-C catalysts $[11,17,39]$ or ii) a high-spin $\mathrm{Fe}^{3+}$ species such as amorphous or $\beta-\mathrm{Fe}_{2} \mathrm{O}_{3}$ with a small particle size [40,41]. It is known that the Mössbauer spectrum of nanometric ferric oxides changes from a doublet to a sextet spectral component below a certain critical temperature [42,43], while that of $\mathrm{D} 1\left(\mathrm{FeN} \mathrm{N}_{\mathrm{x}}\right.$ moiety) is independent of temperature, remaining a doublet even at $5 \mathrm{~K}$ [44]. In order to distinguish between the two possible assignments, the ${ }^{57} \mathrm{Fe}$ Mössbauer spectrum of ICM-FePhen 3 was measured at $5 \mathrm{~K}$ (Figure $3 \mathrm{~b}$ ). In that spectrum, the relative area (RA) of the two sextets assigned to $\mathrm{Fe}_{2} \mathrm{O}_{3}$ (both $\varepsilon+\beta$ ) increased to $62 \%$, while the doublet disappeared. This indicates that the well-defined narrow doublet observed at room temperature was arising from nanometric $\beta-\mathrm{Fe}_{2} \mathrm{O}_{3}$. 
This is also independently confirmed later with high-resolution transmission electron microscopy (HR-TEM) images.

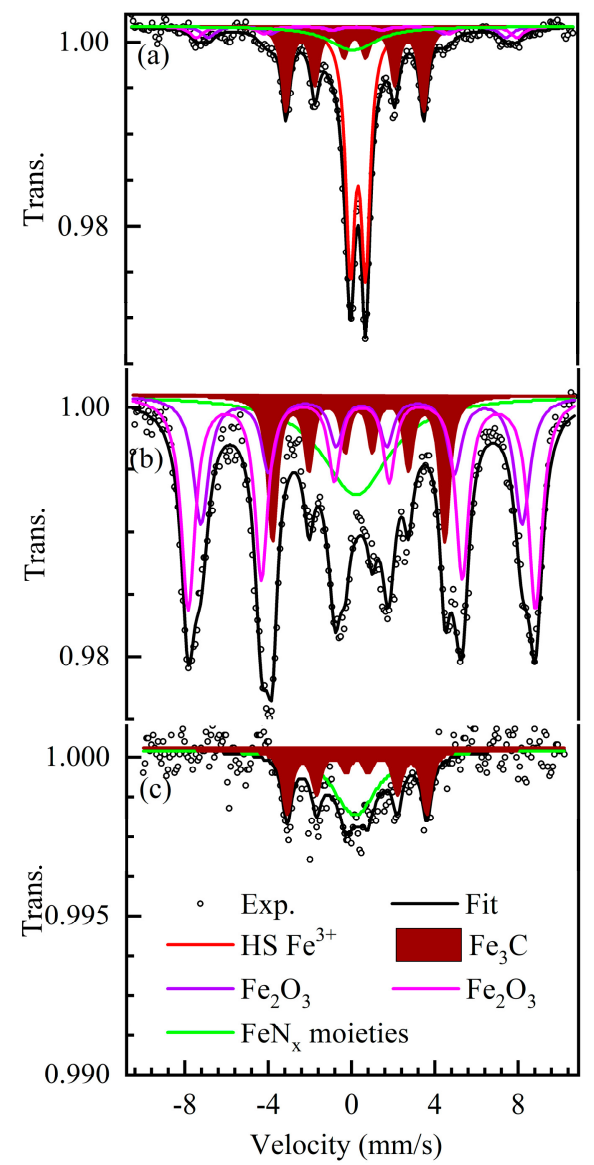

Figure 3. ${ }^{57} \mathrm{Fe}$ Mössbauer transmission spectra and their fittings with spectral components. ICM-FePhen 3 measured at (a) $293 \mathrm{~K}$ and (b) $5 \mathrm{~K}$, and (c) ICM-FePhen 3 -AW measured at $293 \mathrm{~K}$.

Table 1. Mössbauer parameters derived from the fittings: relative area (RA, \%), isomer shift (IS, $\mathrm{mm} / \mathrm{s}$ ), quadrupole splitting (QS, $\mathrm{mm} / \mathrm{s})$, line width ( $\mathrm{LW}, \mathrm{mm} / \mathrm{s}$ ) and magnetic field (H, Tesla) of each component. Subscript number after the RA\% number indicates the error bar, in \%.

\begin{tabular}{|c|c|c|c|c|c|c|c|}
\hline Sample & Comp. & $\begin{array}{c}\text { RA } \\
\%\end{array}$ & $\begin{array}{c}\mathrm{IS} \\
\mathrm{mm} / \mathrm{s}\end{array}$ & $\begin{array}{c}\mathrm{QS} \\
\mathrm{mm} / \mathrm{s}\end{array}$ & $\begin{array}{c}\mathrm{LW} \\
\mathrm{mm} / \mathrm{s}\end{array}$ & $\begin{array}{c}\mathbf{H} \\
\text { Tesla }\end{array}$ & Assignment \\
\hline \multirow{5}{*}{$\begin{array}{l}\text { ICM-FePhen }_{3} \\
\quad 300 \mathrm{~K}\end{array}$} & Singlet & $12_{2}$ & 0.1 & - & 2.7 & - & Unresolved $^{(1)}$ \\
\hline & Doublet & $46_{4}$ & 0.34 & $0.74_{1}$ & 0.54 & - & Nano- $\mathrm{Fe}_{2} \mathrm{O}_{3}$ \\
\hline & Sextet 1 & $6_{1}$ & 0.31 & - & 0.7 & 44.4 & $\mathrm{Fe}_{2} \mathrm{O}_{3}$ \\
\hline & Sextet 2 & $6_{1}$ & 0.31 & - & 0.7 & 47.8 & $\mathrm{Fe}_{2} \mathrm{O}_{3}$ \\
\hline & Sextet 3 & $30_{1}$ & 0.19 & - & 0.48 & 20.6 & $\mathrm{Fe}_{3} \mathrm{C}$ \\
\hline \multirow{4}{*}{$\begin{array}{c}\text { ICM-FePhen }_{3} \\
5 \mathrm{~K}\end{array}$} & Singlet & $22_{2}$ & 0.21 & - & 4.0 & - & Unresolved $^{(1)}$ \\
\hline & Sextet 1 & $23_{2}$ & 0.48 & - & 0.77 & 47.9 & $\mathrm{Fe}_{2} \mathrm{O}_{3}$ \\
\hline & Sextet 2 & $39_{2}$ & 0.49 & - & 0.67 & 51.7 & $\mathrm{Fe}_{2} \mathrm{O}_{3}$ \\
\hline & Sextet 3 & $16_{2}$ & 0.33 & - & 0.49 & 25.7 & $\mathrm{Fe}_{3} \mathrm{C}$ \\
\hline \multirow{2}{*}{$\begin{array}{l}\text { ICM-FePhen } \\
300 \mathrm{~K}\end{array}$} & Singlet & $55_{12}(2)$ & 0.17 & - & 2.6 & - & Unresolved $^{(1)}$ \\
\hline & Sextet & $45_{12}(2)$ & 0.26 & - & 0.5 & 20.8 & $\mathrm{Fe}_{3} \mathrm{C}$ \\
\hline
\end{tabular}

(1) Unresolved from Mössbauer spectroscopy alone (see Table 2 for the assignment of that broad singlet); (2) Those RA $\%$ are only indicative, due to the low signal-to-noise ratio of that spectrum. 
Table 2. Content of each Fe species as obtained from the fitting of ${ }^{57} \mathrm{Fe}$ Mössbauer or Fe K-edge XANES spectra. Subscript number after the RA\% or XANES \% number indicates the error bar, in \%.

\begin{tabular}{|c|c|c|c|c|c|}
\hline Sample & $\begin{array}{l}\text { Mössbauer } \\
\text { Component }\end{array}$ & $\begin{array}{c}\text { Mössbauer RA } \\
\%(300 \mathrm{~K})\end{array}$ & $\begin{array}{c}\text { Mössbauer RA } \\
\%(5 \mathrm{~K})\end{array}$ & $\begin{array}{l}\text { LCF XANES } \\
\text { Reference }\end{array}$ & XANES \% \\
\hline \multirow{3}{*}{ ICM-FePhen $_{3}$} & Singlet & $12_{2}$ & $22_{2}$ & $\mathrm{Fe}_{0.5} \mathrm{NC}$ & $25_{3}$ \\
\hline & $\mathrm{Fe}_{2} \mathrm{O}_{3}{ }^{(1)}$ & 58 & $62_{2}$ & $\mathrm{Fe}_{2} \mathrm{O}_{3}$ & $64_{4}$ \\
\hline & $\mathrm{Fe}_{3} \mathrm{C}$ & $30_{1}$ & $16_{2}$ & $\mathrm{Fe}_{3} \mathrm{C}$ & $11_{1}$ \\
\hline \multirow{3}{*}{ ICM-FePhen $_{3}$-AW } & Singlet & $55_{12}(2)$ & NA & $\mathrm{Fe}_{0.5} \mathrm{NC}$ & $38_{3}$ \\
\hline & $\mathrm{Fe}_{2} \mathrm{O}_{3}$ & 0 & NA & $\mathrm{Fe}_{2} \mathrm{O}_{3}$ & $30_{4}$ \\
\hline & $\mathrm{Fe}_{3} \mathrm{C}$ & $45_{12}{ }^{(2)}$ & NA & $\mathrm{Fe}_{3} \mathrm{C}$ & $32_{1}$ \\
\hline
\end{tabular}

(1) Both the sextet and doublet components assigned to $\mathrm{Fe}_{2} \mathrm{O}_{3}$ particles of different size and/or polymorphs; ${ }^{(2)}$ Those RA \% are only indicative, and poorly reliable due to the low signal-to-noise ratio of that spectrum.

For ICM-FePhen 3 -AW, the analysis of its room-temperature Mössbauer spectrum (Figure 3c) showed first that the magnitude of the $\gamma$-rays absorption was much decreased (synonym with much lower total $\mathrm{Fe}$ content in the sample) and second, that both the sextets of $\varepsilon-\mathrm{Fe}_{2} \mathrm{O}_{3}$ and the intense doublet of $\beta-\mathrm{Fe}_{2} \mathrm{O}_{3}$ observed in ICM-FePhen 3 were no longer visible. Instead, the spectrum clearly showed only the sextet typical for $\mathrm{Fe}_{3} \mathrm{C}$ and the broad singlet component already observed in ICM-FePhen ${ }_{3}$ (Figure 3c). It however cannot be excluded that a small fraction of the narrow doublet assigned to nanosized $\mathrm{Fe}_{2} \mathrm{O}_{3}$ is still present in ICM-FePhen 3 -AW, embedded within the broad singlet. These results can be interpreted as the complete or nearly-complete removal of the $\mathrm{Fe}_{2} \mathrm{O}_{3}$ (nano)particles during the acid wash, while a significant fraction of $\mathrm{Fe}_{3} \mathrm{C}$ was not dissolved. Last, the singlet with unusually large line width (in green color in Figure 3) was present in all three Mössbauer spectra and is a spectral component previously identified in complex $\mathrm{Fe}-\mathrm{N}-\mathrm{C}$ materials comprising numerous Fe species [45]. It represents only $12 \%$ of the Fe signal in ICM-FePhen 3 but $55 \%$ in ICM-FePhen 3 -AW (Table 1), suggesting it corresponds to a species that is stable in acidic medium. As will be seen later, its assignment can only be made after discussing the XAS results.

In order to further study the coordination environments of iron, XAS measurements at the Fe K-edge were performed on ICM-FePhen ${ }_{3}$ and ICM-FePhen 3 -AW, as well as on selected reference compounds. The similar X-ray absorption near edge structure (XANES) spectra (Figure 4a) of ICM-FePhen ${ }_{3}$ and a $\mathrm{Fe}_{2} \mathrm{O}_{3}$ reference and their corresponding Fourier Transforms (FT) of the extended X-ray absorption fine structure (EXAFS) spectra (Figure $4 \mathrm{~b}$ ) confirmed that $\mathrm{Fe}_{2} \mathrm{O}_{3}$ is the dominant iron component in ICM-FePhen ${ }_{3}$, agreeing well with the Mössbauer results. The shoulder at $2.1 \AA$ and the strong peak at $2.5 \AA$ coincided with the $\mathrm{Fe}-\mathrm{Fe}$ backscattering from $\mathrm{Fe}_{3} \mathrm{C}$ standards for the former, and $\mathrm{Fe}_{2} \mathrm{O}_{3}$ for the latter (Figure $4 \mathrm{~b}$ ). The removal of most of $\mathrm{Fe}_{2} \mathrm{O}_{3}$ by acid wash was confirmed by the much lower intensity of the peak at ca $2.5 \AA$ in the FT-EXAFS signal of ICM-FePhen ${ }_{3}$-AW relative to ICM-FePhen 3 . Moreover, the FT-EXAFS spectrum of ICM-FePhen 3 -AW (Figure $4 b$ ) exhibited a major peak at $1.5 \AA$ that can be attributed either to Fe-N contribution from $\mathrm{FeN}_{\mathrm{x}}$ moieties and/or $\mathrm{Fe}-\mathrm{O}$ contribution from $\mathrm{Fe}_{2} \mathrm{O}_{3}$. 

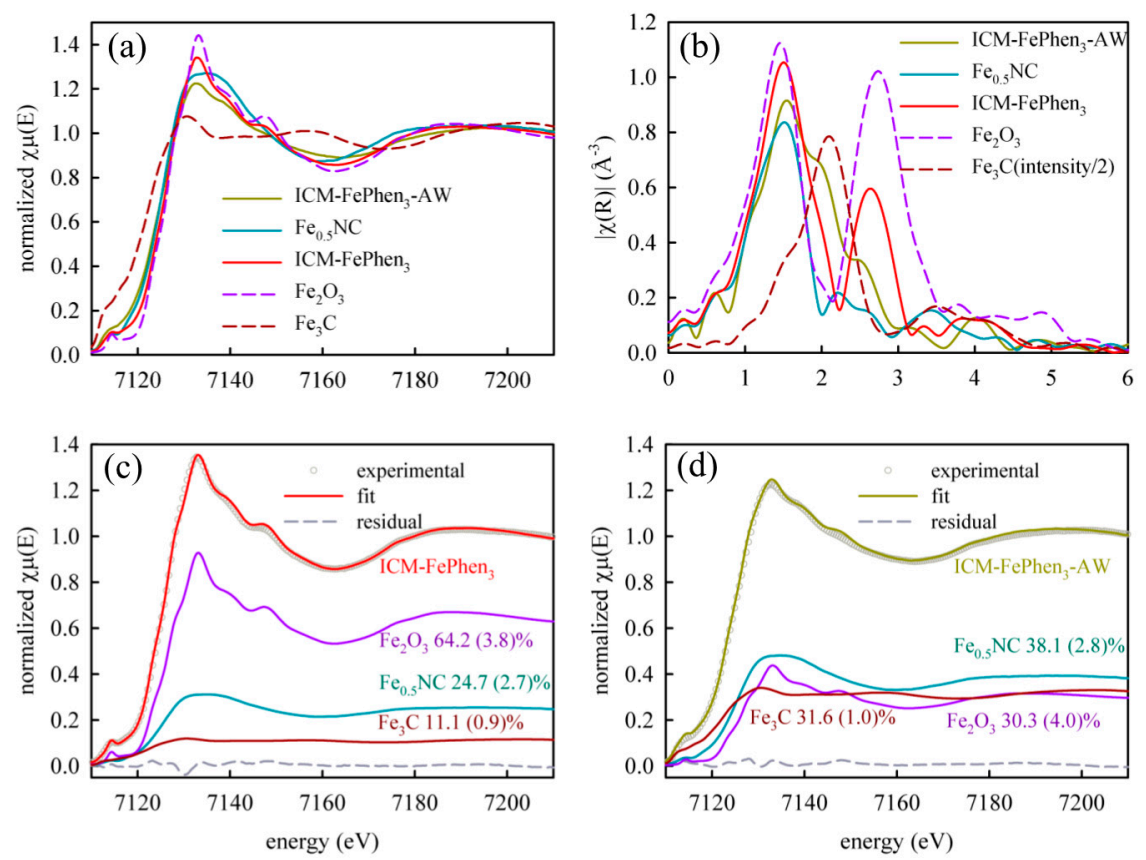

Figure 4. X-ray absorption spectroscopy characterization of ICM-FePhen 3 and ICM-FePhen 3 -AW. (a) Fe k-edge X-ray absorption near edge structure (XANES) spectra, (b) Fourier transforms of the extended $\mathrm{X}$-ray absorption fine structure (EXAFS) spectra. The spectra of $\mathrm{Fe}_{2} \mathrm{O}_{3}, \mathrm{Fe}_{3} \mathrm{C}$ and $\mathrm{Fe}_{0 .} \mathrm{NC}$ (an Fe-N-C material comprising exclusively atomically dispersed $\mathrm{FeN}_{\mathrm{x}}$ moieties [11]) are also shown. Linear combination fitting (LCF) of the Fe k-edge XANES spectra of (c) ICM-FePhen 3 and (d) ICM-FePhen 3 -AW with $\mathrm{Fe}_{2} \mathrm{O}_{3}, \mathrm{Fe}_{3} \mathrm{C}$ and $\mathrm{Fe}_{0.5} \mathrm{NC}$ as references. Error bars are given in parentheses.

In order to go beyond the limitations of Mössbauer spectroscopy (unresolved broad singlet component), we then performed linear combination fitting (LCF) of the XANES spectra of ICM-FePhen 3 (Figure 4c) and ICM-FePhen 3 -AW (Figure 4d) with three reference spectra, namely $\mathrm{Fe}_{2} \mathrm{O}_{3}, \mathrm{Fe}_{3} \mathrm{C}$ and $\mathrm{Fe}_{0.5} \mathrm{NC}$ (the latter comprising exclusively $\mathrm{Fe}$ as atomically dispersed $\mathrm{FeN}_{\mathrm{x}}$ moieties [3]). The XANES spectrum of ICM-FePhen ${ }_{3}$ was well fitted with a combination involving the above three components. Their relative amounts are shown in Table 2, and agree well with the RA $\%$ of $\mathrm{Fe}_{2} \mathrm{O}_{3}, \mathrm{Fe}_{3} \mathrm{C}$ and of the broad singlet quantified from the 5K Mössbauer-spectra fittings. Thus, for ICM-FePhen 3 , the broad singlet identified in the Mössbauer spectrum can be entirely assigned to $\mathrm{FeN}_{\mathrm{x}}$ moieties.

For ICM-FePhen 3 - AW, the three components of $\mathrm{Fe}_{2} \mathrm{O}_{3}, \mathrm{Fe}_{3} \mathrm{C}$ and $\mathrm{Fe}_{0.5} \mathrm{NC}$ were also needed to get the best LCF fit of its XANES spectrum (Figure 4d), including $30 \%$ of the reference $\mathrm{Fe}_{2} \mathrm{O}_{3}$ spectrum and $38 \%$ of the reference $\mathrm{Fe}_{0.5} \mathrm{NC}$ spectrum. LCF with only the $\mathrm{Fe}_{3} \mathrm{C}$ and $\mathrm{Fe}_{0.5} \mathrm{NC}$ references resulted in a clearly poorer fit quality (especially at the white line intensity region), confirming the presence of $\mathrm{Fe}_{2} \mathrm{O}_{3}$ in ICM-FePhen ${ }_{3}$-AW (Supporting Figure S1). This is in contrast with the Mössbauer analysis, which could not identify the presence of $\mathrm{Fe}_{2} \mathrm{O}_{3}$ or nano $\mathrm{Fe}_{2} \mathrm{O}_{3}$, probably due to the low signal-to-noise ratio. The presence of $\mathrm{Fe}_{2} \mathrm{O}_{3}$ in ICM-FePhen 3 - $\mathrm{AW}$ is also supported by the peak at ca $2.5 \AA$ in the FT-EXAFS spectrum (Figure $3 \mathrm{~b}$ ) and by elemental mapping results (shown later).

The LCF XANES analysis and FT-EXAFS spectra thus indicate that the ICM-FePhen ${ }_{3}$-AW sample contains three Fe species: $\mathrm{Fe}_{3} \mathrm{C}, \mathrm{FeN}_{\mathrm{x}}$ moieties and nanosized $\mathrm{Fe}_{2} \mathrm{O}_{3}$. Since only two spectral components have been used for the Mössbauer fitting of that sample, the comparison of RA\% and XANES LCF \% is less straightforward. The broad singlet used for the Mössbauer fitting of that catalyst probably includes both the signal from $\mathrm{FeN}_{\mathrm{x}}$ moieties and from nano- $\mathrm{Fe}_{2} \mathrm{O}_{3}$, and this indicates that the $\mathrm{RA} \%$ for the singlet and for $\mathrm{Fe}_{3} \mathrm{C}$ indicated in Table 1 for ICM-FePhen ${ }_{3}-\mathrm{AW}$ is not reliable (as initially expected also from the high noise level of that spectrum). In conclusion, the combined Mössbauer, XANES and EXAFS analysis indicates that both ICM-FePhen ${ }_{3}$ and ICM-FePhen ${ }_{3}-\mathrm{AW}$ contain $\mathrm{FeN}_{\mathrm{x}}$ moieties. These sites were present already in ICM-FePhen ${ }_{3}$ and survived the acid wash, and probably 
worked as the major active sites for ORR in acidic medium. This hypothesis would explain the similar ORR activity of ICM-FePhen ${ }_{3}$ and ICM-FePhen 3 -AW in acidic medium.

\subsection{Porous Structure and Morphology}

Following the carbon bulk structure and Fe speciation characterization, the porous structure of ICM-FePhen 3 was investigated with $\mathrm{N}_{2}$ adsorption/desorption isotherms. The hysteresis loop (assigned to small mesopores) and the slope of the $\mathrm{N}_{2}$ adsorption/desorption isotherm of ICM-FePhen 3 (assigned to large mesopores) (Figure 5a), as well as the corresponding pore size distribution (calculated from density functional theory (DFT) method, Figure $5 b$ ) indicated the mesoporous structure of the carbon matrix, with a volume-average pore size around $3.4 \mathrm{~nm}$ (Table 3) [46].
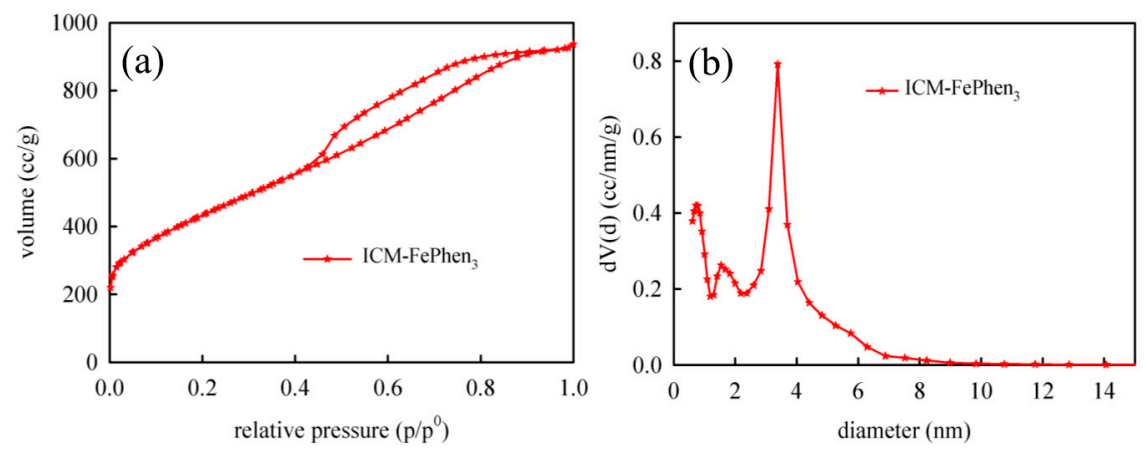

Figure 5. (a) $\mathrm{N}_{2}$ adsorption/desorption isotherm, and (b) the corresponding pore size distribution from density functional theory (DFT) method of ICM-derived Fe-N-C catalysts.

Table 3. Surface area, pore volume and pore size of ICM-FePhen 3 catalyst based on $\mathrm{N}_{2}$ physisorption isotherm analysis.

\begin{tabular}{ccccc}
\hline \multirow{2}{*}{ Sample } & $\begin{array}{c}\text { BET Surface Area } \\
\left(\mathbf{m}^{2} / \mathbf{g}\right)\end{array}$ & \multicolumn{2}{c}{ Pore Volume (cc/g) } & Pore Size (nm) \\
\cline { 3 - 5 } & 1546.0 & Single Point & DFT & DFT \\
\hline ICM-FePhen $_{3}$ & 1.5 & 1.4 & 3.4 \\
\hline
\end{tabular}

Last, the morphology of ICM-FePhen ${ }_{3}-\mathrm{AW}$ was further studied with scanning electron microscopy (SEM) and high-angle annular dark-field scanning transmission electron microscopy (HAADF-STEM). Tubular-shaped, hollow carbon matrixes with diameters around $60 \mathrm{~nm}$ were observed from the SEM image (Figure 6a). The HAADF-STEM images (Figure 6c-e) identified a highly porous structure of the catalyst, agreeing well with the high double layer capacitance from CVs (Figure 1b,d) and the high BET surface areas ( $1500 \mathrm{~m}^{2} / \mathrm{g}$, Table 3$)$. The obtained hierarchically porous structure was arisen from the $\mathrm{ZnCl}_{2} / \mathrm{NaCl}$ eutectic salts introduced in the catalyst precursor [22]. The elemental compositions were investigated by energy dispersive X-ray spectroscopy (EDX). Carbon, oxygen and iron were present in the sample (Figure 6f). It should be noted that nitrogen was not analyzed due to the close energy between $\mathrm{C}$ and $\mathrm{N}$, and the stronger signal of $\mathrm{C}$. Moreover, trace amount of $\mathrm{S}$ (introduced from acid wash with $\mathrm{H}_{2} \mathrm{SO}_{4}$ ), $\mathrm{Si}$ (from the quartz tube and quartz boat used during pyrolysis) and $\mathrm{Ni}$ (from the TEM grid) were also detected by EDX. Aggregated Fe particles with different sizes were also observed in HAADF-STEM images for ICM-FePhen 3 -AW (Figure 6b-e). The EDX elemental mapping results suggested that these particles are iron oxides, or oxidized $\mathrm{Fe}_{3} \mathrm{C}$ (Figure $6 \mathrm{~g}-\mathrm{j}$ ), and they survived the acid wash probably due to protection of the carbon shell. This is in line with the peak at ca $2.5 \AA$ assigned to Fe-Fe backscattering from Fe oxides in the FT-EXAFS spectrum of ICM-FePhen ${ }_{3}-\mathrm{AW}$, as well as the LCF of its XANES spectrum. 

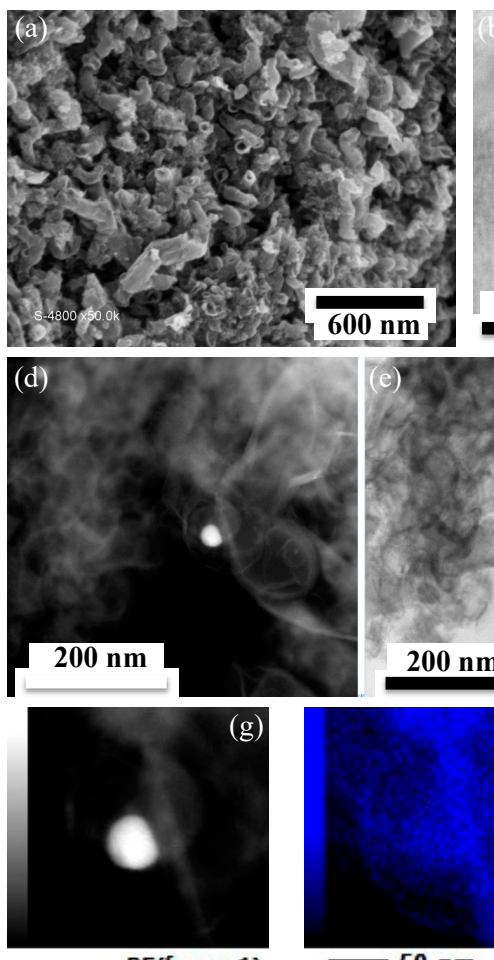

BF(frame1)
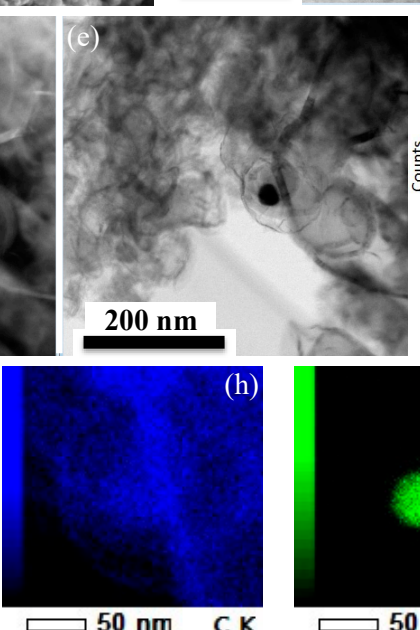
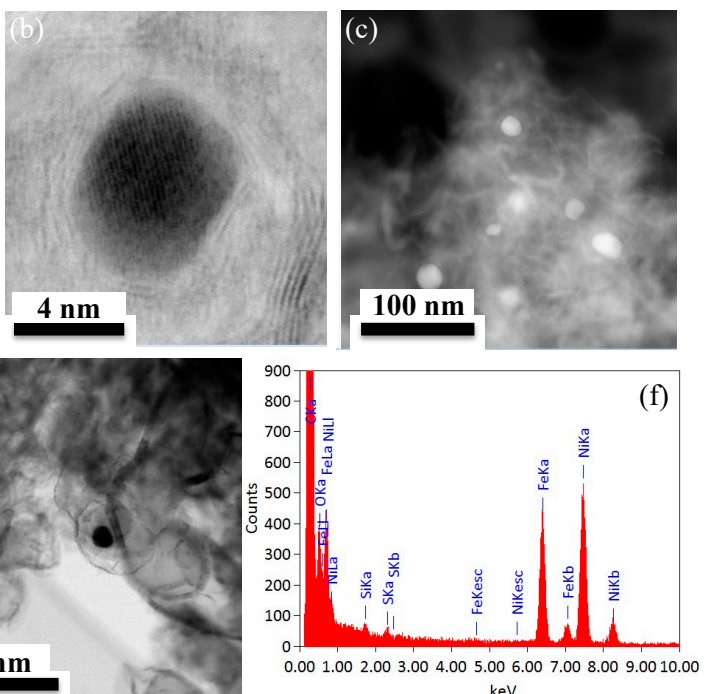

$\mathrm{keV}$
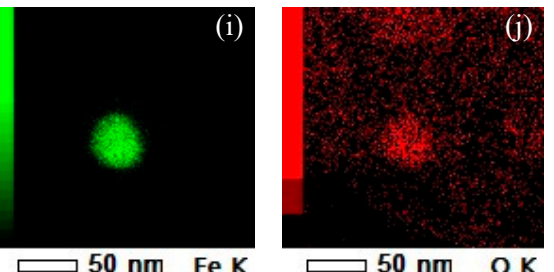

Figure 6. (a) Scanning electron microscopy (SEM) image of ICM-FePhen $3-A W ;(b, e)$ bright-field scanning transmission electron microscopy (BF-STEM) and (c,d) high-angle annular dark-field (HAADF)-STEM images, (f) energy dispersive X-ray spectroscopy (EDX) spectrum measured in the same area as $(\mathbf{d})$ and $(\mathbf{e})$, and $(\mathbf{g}-\mathbf{j})$ the corresponding elemental mapping.

\section{Discussion}

Based on the results and analyses, the ICM-FePhen 3 catalyst comprises mainly $\mathrm{Fe}_{2} \mathrm{O}_{3}(60-68 \%)$ together with $\mathrm{FeN}_{\mathrm{x}}$ moieties (20-28\%) and $\mathrm{Fe}_{3} \mathrm{C}(10-18 \%)$. After acid wash, the ICM-FePhen ${ }_{3}-\mathrm{AW}$ sample still comprises Fe in these three different environments, but now in comparable relative contents (26-34\% $\mathrm{Fe}_{2} \mathrm{O}_{3}, 35-41 \% \mathrm{FeN}_{\mathrm{x}}$ moieties, 31-33\% $\mathrm{Fe}_{3} \mathrm{C}$ ). The majority of $\mathrm{Fe}_{2} \mathrm{O}_{3}$ particles in ICM-FePhen 3 were thus removed by acid wash. The $\mathrm{Fe}_{2} \mathrm{O}_{3}$ particles still observed after acid wash may have been protected from the acid leaching by a surrounding carbon layer, and/or may have formed from the partial oxidation of $\mathrm{Fe}_{3} \mathrm{C}$ particles during the acid wash. The almost-superimposed ORR activity in acidic medium of ICM-FePhen ${ }_{3}$ and ICM-FePhen ${ }_{3}-\mathrm{AW}$ suggests that all or most of the $\mathrm{FeN}_{\mathrm{x}}$ moieties

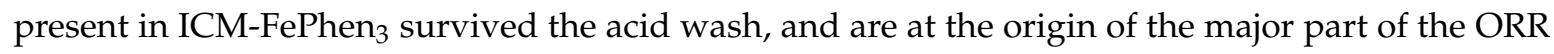
activity of both samples, in line with the current consensus in the field that $\mathrm{FeN}_{\mathrm{x}}$ sites are the most active Fe-sites in acidic medium $[11,14,17,47]$. The slightly lower ORR activity of ICM-FePhen ${ }_{3}$-AW vs. ICM-FePhen ${ }_{3}$ may be assigned to a small contribution of $\mathrm{Fe}_{3} \mathrm{C}$ particles to the ORR activity of ICM-FePhen ${ }_{3}$, or to the removal by acid wash of a few $\mathrm{FeN}_{\mathrm{x}}$ moieties with low stability. For the former hypothesis, the acid wash is expected to remove $\mathrm{Fe}_{3} \mathrm{C}$ particles that are either unprotected by a carbon layer, or protected by a thin or porous $\mathrm{N}$-doped carbon layer, while $\mathrm{Fe}_{3} \mathrm{C}$ particles with a thick graphite shell protection are expectedly stable to an acid wash. Since $\mathrm{Fe}_{3} \mathrm{C}$ particles surrounded by a thin $\mathrm{N}$-doped carbon layer have been shown to possess some ORR activity in acidic medium, but also to be poorly stable due to defects in their carbon shell, it is possible that the small decrease in ORR activity of ICM-FePhen 3 -AW vs. ICM-FePhen 3 comes from the removal of a fraction of the $\mathrm{Fe}_{3} \mathrm{C}$ particles. $\mathrm{FeN}_{\mathrm{x}}$ moieties were identified in both the ICM-FePhen 3 and ICM-FePhen ${ }_{3}-\mathrm{AW}$ catalysts, with the former showing a clear redox peak in $\mathrm{N}_{2}$-saturated $\mathrm{CV}$, while the latter exhibiting a redox peak at similar position with much lower intensity (Figure 1d). The redox signal of $\mathrm{FeN}_{\mathrm{x}}$ moieties in pyrolyzed $\mathrm{Fe}-\mathrm{N}-\mathrm{C}$ catalysts is often weak and broad, necessitating to resort to square-wave voltammetry to 
identify it. Thus, while the position of this redox peak fits well with that assigned to $\mathrm{FeN}_{\mathrm{x}}$ moieties, the overall redox signal of ICM-FePhen 3 may originate from both $\mathrm{FeN}_{\mathrm{x}}$ moieties and, mostly, from $\mathrm{Fe}_{2} \mathrm{O}_{3}$ particles. This would also explain the reduced peak intensity of ICM-FePhen $3-\mathrm{AW}$, as the majority of $\mathrm{Fe}_{2} \mathrm{O}_{3}$ was removed via acid wash. The residual redox signal after acid wash possibly originates from $\mathrm{FeN}_{\mathrm{x}}$ moieties and/or the residual $\mathrm{Fe}_{2} \mathrm{O}_{3}$.

In alkaline medium however, the ORR activity of ICM-FePhen $3-\mathrm{AW}$ is significantly lower than that of ICM-FePhen 3 (Figure 1c), and this is paralleled by the removal of a large fraction of $\mathrm{Fe}_{2} \mathrm{O}_{3}$ during the acid wash. This suggests that one or several polymorphs of $\mathrm{Fe}_{2} \mathrm{O}_{3}$ contributed largely to the overall ORR activity of ICM-FePhen ${ }_{3}$ in alkaline. This is in line with the previously reported ORR activity

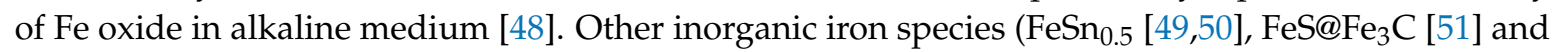
$\mathrm{Fe}_{2} \mathrm{P} @ \mathrm{Fe}_{4} \mathrm{P}$ [52]) have been reported to be ORR active as well, and they generally exhibit much superior ORR activity in alkali compared to that in acid, agreeing well with our results. $\mathrm{Fe}_{3} \mathrm{C}$ is also present in ICM-FePhen ${ }_{3}$ and may have contributed to the overall ORR activity in alkaline medium. While in acid medium, the ORR activity of ICM-FePhen ${ }_{3}$ is mostly assigned to $\mathrm{FeN}_{\mathrm{x}}$ moieties, the contribution to the overall ORR activity of $\mathrm{Fe}_{3} \mathrm{C}$ particles encapsulated in nitrogen-doped graphene may be higher in alkaline medium due to a stronger enhancement of the ORR turnover frequency with $\mathrm{pH}$ changing from 1 to 13 for $\mathrm{N}$-doped carbon (with or without subsurface $\mathrm{Fe}_{3} \mathrm{C}$ ) than for $\mathrm{FeN}_{\mathrm{x}}$ moieties. Both experimental results $[37,53]$ and theoretical calculations [54] have proved the ORR activity of $\mathrm{Fe}_{3} \mathrm{C}$ particles encapsulated in nitrogen-doped graphene.

It should be noted that the major iron species in the present ICM-derived $\mathrm{Fe}-\mathrm{N}-\mathrm{C}$ catalysts is Fe oxides, and the site density of $\mathrm{FeN}_{\mathrm{x}}$ moieties is quite low. This explains the relatively low ORR activity in acidic medium of the present ICM-derived Fe-N-C catalysts compared to state-of-the-art $\mathrm{Fe}-\mathrm{N}-\mathrm{C}$ catalysts $[11,14,17,39,47]$. The low site density of $\mathrm{FeN}_{\mathrm{x}}$ moieties seems correlated to the high degree of graphitization of the carbon matrix derived from the ICM approach, as compared to the amorphous carbons usually obtained from the pyrolysis of ZIF-8. The present approach even requires the pre-existing $\mathrm{Fe}-\mathrm{N}_{4}(\mathrm{FePc})$ or $\mathrm{Fe}-\mathrm{N}_{6}\left(\mathrm{FePhen}_{3}\right)$ coordination as iron precursors to obtain reasonable ORR activity after pyrolysis. This suggests that there is a synthetic contradiction between the desires for a high density of $\mathrm{FeN}_{\mathrm{x}}$ sites (necessary to reach a high ORR activity) and a high degree of graphitization of carbon (possibly leading to improved stability). Highly graphitized carbons with few defects typically result in low nitrogen content, in turn limiting the maximum number of $\mathrm{FeN}_{\mathrm{x}}$ moieties that may be hosted in the carbon matrix.

\section{Materials and Methods}

Sample preparation. All catalyst precursors were prepared via the dry ball-milling of $\mathrm{Zn}$ (II) chloride, $\mathrm{Na}$ (I) chloride, adenine and an iron precursor. A mass of $100 \mathrm{mg}$ of adenine, $825 \mathrm{mg}$ of $\mathrm{ZnCl}_{2}, 175 \mathrm{mg}$ of $\mathrm{NaCl}$ and certain amount of iron precursor (iron(II) phthalocyanine (FePc), 1,10-phenanthroline iron (II) perchlorate $\left(\mathrm{FePhen}_{3}\right)$, or iron (II) acetate $\left(\mathrm{FeAc}_{2}\right)$ corresponding to $4 \mathrm{wt} . \%$ $\mathrm{Fe}$ in the total precursor (the inorganic $\mathrm{ZnCl}_{2} / \mathrm{NaCl}$ salts not being counted) were weighed and poured into a $\mathrm{ZrO}_{2}$ crucible with hundred zirconium-oxide balls of $5 \mathrm{~mm}$ diameter. When using $\mathrm{FeAc}_{2}$ as Fe precursor, 1,10-phenanthroline was added to reach the stoichiometry Fe:Phen of 1:3, to ensure all catalyst precursors possessed similar nitrogen contents before pyrolysis. $\mathrm{The}_{\mathrm{ZrO}} \mathrm{Crucible}$ was then sealed under air and placed in a planetary ball-miller (Fritsch Pulverisette 7 Premium, Fritsch, Idar-Oberstein, Germany). The powders were ball-milled for $30 \mathrm{~min}$ at $200 \mathrm{rpm}$ milling speed, then pyrolyzed in flash mode at $900{ }^{\circ} \mathrm{C}$ in flowing Ar for $1 \mathrm{~h}$. Then they were washed in deionized water for 48 hours at room temperature to remove $\mathrm{NaCl}$ and finally dried. The catalysts are labelled "ICM-Fe-precursor". In some cases, the washing after pyrolysis was performed in $0.5 \mathrm{M}$ $\mathrm{H}_{2} \mathrm{SO}_{4}$ rather than in water, in otherwise the same conditions. The catalysts are labelled in this case ICM-Fe-precursor-AW.

Electrochemical characterization. The catalyst powders were deposited on glassy carbon electrodes as working electrode. Catalyst ink was prepared by dispersing $10 \mathrm{mg}$ of the catalyst 
powder in a mixture of Millipore water $(36.5 \mu \mathrm{L}, 18.2 \mathrm{M} \Omega \mathrm{cm})$ and ethanol (300 $\mu \mathrm{L}$, Sigma-Aldrich, 99.8\%, Lyon, France), into which $5 \mathrm{wt} \%$ Nafion solution (108.5 $\mu \mathrm{L}$, Sigma-Aldrich, Lyon, France) was added as a binder phase. The resulting mixture was sonicated for $60 \mathrm{~min}$, and then an aliquot of $7 \mu \mathrm{L}$ was drop-cast onto the glassy carbon electrodes $\left(0.196 \mathrm{~cm}^{2}\right.$, Pine instrument, Grove City, PA, USA), resulting in a loading of $800 \mu \mathrm{g} / \mathrm{cm}^{2}$. The working electrode with the deposited catalyst layer was used in a three-electrode cell set-up connected to a bipotentiostat (Biologic SP 300, Bio-Logic Science Instruments, Isère, France) and rotator (Pine Instruments, Grove City, PA, USA). The graphite rod and reversible hydrogen electrode (RHE) were used as counter and reference electrodes, respectively. The ORR activity was measured in $\mathrm{O}_{2}$-saturated $0.1 \mathrm{M} \mathrm{HClO}_{4}$ or $0.1 \mathrm{M} \mathrm{KOH}$ from 0.05 to $1.05 \mathrm{~V}$ vs. RHE with a scan rate of $20 \mathrm{mV} / \mathrm{s}$ at 1,600 rpm. The cycle voltammetry $(\mathrm{CV})$ was carried out between 0.05 to $1.05 \mathrm{~V}$ vs. RHE with a scan rate of $20 \mathrm{mV} / \mathrm{s}$ in $\mathrm{N}_{2}$-saturated $0.1 \mathrm{M} \mathrm{HClO}_{4}$.

XRD. X-ray diffraction patterns were conducted using a PANanalytical X'Pert Pro powder X-ray diffractometer (Malvern Panalytical Ltd, Malvern, UK) with $\mathrm{Cu} \mathrm{K}_{\alpha}$ radiation.

Raman. Raman spectra were collected using a LabRAM ARAMIS Raman microscope (HORIBA, Kyoto, Japan) with a $473 \mathrm{~nm}$ laser.

BET. $\mathrm{N}_{2}$ sorption analysis was performed at liquid nitrogen temperature $(77 \mathrm{~K})$ with a Micromeritics ASAP 2020 instrument (Micromeritics, Verneuil-en-Halatte, France). Prior to the measurements, FeNC-ICM catalysts were degassed at $200{ }^{\circ} \mathrm{C}$ for $5 \mathrm{~h}$ in flowing nitrogen to remove guest molecules or moisture. The pore size distributions were calculated by fitting the full isotherm with the quench solid density functional theory model with slit pore geometry from NovaWin (Quantachrome Instruments).

Mössbauer spectroscopy. ${ }^{57} \mathrm{Fe}$ Mössbauer spectroscopy was used to obtain information on iron speciation. 120 to $300 \mathrm{mg}$ samples were mounted in a $2-\mathrm{cm}^{2}$ holder. Mössbauer spectra were measured at variable temperatures between 5 and $300 \mathrm{~K}$ in a helium flow cryostat (SHI-850 Series from Janis, Woburn, MA, USA). The Mössbauer spectrometer (Wissel, Germany) was operated in the transmission mode with a ${ }^{57} \mathrm{Co}$ : Rh source at room temperature. The velocity driver was operated in the constant acceleration mode with a triangular velocity waveform. The velocity scale was calibrated with the magnetically split sextet of a high-purity $\alpha$-Fe foil at room temperature. The spectra were fitted to appropriate combinations of Lorentzian profiles representing quadrupole doublets, sextets by least-squares methods. Isomer shifts are given relative to $\alpha$-Fe at room temperature.

XAS. Fe K-edge X-ray absorption spectra were collected at room temperature in transmission mode at SAMBA beamline (Synchrotron SOLEIL, Saint-Aubin, France). The beamline is equipped with a sagittally focusing Si 220 monochromator and two Pd-coated mirrors that were used to remove $\mathrm{X}$-rays harmonics. The catalysts were pelletized as disks of $10-\mathrm{mm}$ diameter with 1-mm thickness using Teflon powder (1- $\mu \mathrm{m}$ particle size) as a binder. Data treatment and linear combination fitting (LCF) were performed with the Athena software [55].

SEM. Scanning electron microscopy micrographs were obtained with a Hitachi S-4800 apparatus (Hitachi, Tokyo, Japan).

TEM. Transmission electron microscopy micrographs were obtained with a JEOL ARM-200 CF probe Cs-corrected scanning transmission electron microscope (JEOL, Tokyo, Japan), operated at $80 \mathrm{kV}$ and equipped with Centurio $100 \mathrm{~mm}^{2}$ SDD EDXS system and Gatan GIF Quantum ER Dual EELS system.

\section{Conclusions}

$\mathrm{ZnCl}_{2} / \mathrm{NaCl}$ eutectic salts assisted carbonization was demonstrated to be an effective approach to synthesize $\mathrm{Fe}-\mathrm{N}-\mathrm{C}$ catalysts when using iron precursors with pre-existing $\mathrm{Fe}-\mathrm{N}$ coordination $\left(\mathrm{FePc}\right.$ and $\left.\mathrm{FePhen}_{3}\right)$. The obtained catalysts exhibited a highly porous structure and a high degree of graphitization. However, it is a challenge to form a high density of $\mathrm{FeN}_{\mathrm{x}}$ sites in graphitized carbon, probably due to the low nitrogen content in the graphitic matrix. Iron precursors with pre-existing $\mathrm{Fe}-\mathrm{N}_{\mathrm{x}}$ coordination was required to form a small content of $\mathrm{FeN}_{\mathrm{x}}$ moieties at high temperature, while 
separate $\mathrm{Fe}$ and $\mathrm{N}$ precursors lead to an inactive $\mathrm{Fe}-\mathrm{N}-\mathrm{C}$ material. Even for the most active samples, a variety of iron species was detected in the FeNC-ICM catalysts, including $\mathrm{FeN}_{\mathrm{x}}$ moieties but also Fe carbides and, mostly, Fe oxides (different sizes and polymorphs). From a comparison of the ORR activity in acid and alkaline conditions for two catalysts (a fresh and an acid-washed version of the same starting material), the $\mathrm{FeN}_{\mathrm{x}}$ moieties were identified as the most active sites in acid medium, while both $\mathrm{FeN}_{\mathrm{x}}$ moieties and $\mathrm{Fe}_{2} \mathrm{O}_{3}$ oxides are proposed to promote ORR in alkaline electrolyte. The ORR activity of $\mathrm{Fe}_{3} \mathrm{C}$ particles encapsulated in nitrogen-doped graphene cannot be excluded in either acid or alkali, with different contributions to the overall activity.

Supplementary Materials: The following are available online at http:/ /www.mdpi.com/2073-4344/9/2/144/s1, Figure S1: Linear combination fitting of the Fe k-edge XANES spectra of ICM-FePhen ${ }_{3}-\mathrm{AW}$ with $\mathrm{Fe}_{3} \mathrm{C}$ and $\mathrm{Fe}_{0.5} \mathrm{NC}$ as references.

Author Contributions: Conceptualization, J.L., F.J., Q.J. and S.M.; methodology, J.L., F.J. and Q.J.; electrochemical data acquisition and analysis, J.L.; XAS data acquisition and analysis, J.L., Q.J. and A.Z.; Mossbauer data acquisition and analysis, M.-T.S.; TEM data acquisition and analysis, G.D.; writing-original draft preparation, J.L.; writing—review and editing, J.L., F.J., Q.J., S.M., A.Z., M.-T.S., G.D.

Funding: This research was partially funded by the European Union's Horizon 2020 research and innovation programme under the grant agreement number No. 721065 (project CREATE).

Acknowledgments: We acknowledge Synchrotron SOLEIL (Gif-sur Yvette, France) for provision of synchrotron radiation facilities at beamline SAMBA (proposal number 20180635). G.D. acknowledges the financial support from the Slovenian Research Agency (P2-0393).

Conflicts of Interest: The authors declare no conflict of interest. The funders had no role in the design of the study; in the collection, analyses, or interpretation of data; in the writing of the manuscript, or in the decision to publish the results.

\section{References}

1. Kulkarni, A.; Siahrostami, S.; Patel, A.; Nørskov, J.K. Understanding catalytic activity trends in the oxygen reduction reaction. Chem. Rev. 2018, 118, 2302-2312. [CrossRef] [PubMed]

2. Sui, S.; Wang, X.; Zhou, X.; Su, Y.; Riffat, S.; Liu, C.-J. A comprehensive review of Pt electrocatalysts for the oxygen reduction reaction: Nanostructure, activity, mechanism and carbon support in PEM fuel cells. J. Mater. Chem. A 2017, 5, 1808-1825. [CrossRef]

3. Nie, Y.; Li, L.; Wei, Z. Recent advancements in Pt and Pt-free catalysts for oxygen reduction reaction. Chem. Soc. Rev. 2015, 44, 2168-2201. [CrossRef] [PubMed]

4. Setzler, B.P.; Zhuang, Z.; Wittkopf, J.A.; Yan, Y. Activity targets for nanostructured platinum-group-metal-free catalysts in hydroxide exchange membrane fuel cells. Nat. Nanotechnol. 2016, 11, 1020-1025. [CrossRef] [PubMed]

5. Shao, M.; Chang, Q.; Dodelet, J.-P.; Chenitz, R. Recent advances in electrocatalysts for oxygen reduction reaction. Chem. Rev. 2016, 116, 3594-3657. [CrossRef] [PubMed]

6. Chattot, R.; Bacq, O.L.; Beermann, V.; Kühl, S.; Herranz, J.; Henning, S.; Kühn, L.; Asset, T.; Guétaz, L.; Renou, G.; et al. Surface distortion as a unifying concept and descriptor in oxygen reduction reaction electrocatalysis. Nat. Mater. 2018, 17, 827-833. [CrossRef]

7. Huang, X.; Zhao, Z.; Cao, L.; Chen, Y.; Zhu, E.; Lin, Z.; Li, M.; Yan, A.; Zettl, A.; Wang, Y.M.; et al. High-performance transition metal-doped $\mathrm{Pt}_{3} \mathrm{Ni}$ octahedra for oxygen reduction reaction. Science 2015, 348, 1230-1234. [CrossRef]

8. Stamenkovic, V.R.; Fowler, B.; Mun, B.S.; Wang, G.; Ross, P.N.; Lucas, C.A.; Marković, N.M. Improved oxygen reduction activity on $\mathrm{Pt}_{3} \mathrm{Ni}(111)$ via increased surface site availability. Science 2007, 315, 493-497. [CrossRef]

9. Chong, L.; Wen, J.; Kubal, J.; Sen, F.G.; Zou, J.; Greeley, J.; Chan, M.; Barkholtz, H.; Ding, W.; Liu, D.-J. Ultralow-loading platinum-cobalt fuel cell catalysts derived from imidazolate frameworks. Science 2018, 362, 1276-1281. [CrossRef]

10. Rosli, N.F.; Mayorga-Martinez, C.C.; Latiff, N.M.; Rohaizad, N.; Sofer, Z.; Fisher, A.C.; Pumera, M. Layered $\mathrm{PtTe}_{2}$ matches electrocatalytic performance of $\mathrm{Pt} / \mathrm{C}$ for oxygen reduction reaction with significantly lower toxicity. ACS Sustain. Chem. Eng. 2018, 6, 7432-7441. [CrossRef] 
11. Zitolo, A.; Goellner, V.; Armel, V.; Sougrati, M.-T.; Mineva, T.; Stievano, L.; Fonda, E.; Jaouen, F. Identification of catalytic sites for oxygen reduction in iron-and nitrogen-doped graphene materials. Nat. Mater. 2015, 14, 937-942. [CrossRef] [PubMed]

12. Zitolo, A.; Ranjbar-Sahraie, N.; Mineva, T.; Li, J.; Jia, Q.; Stamatin, S.; Harrington, G.F.; Lyth, S.M.; Krtil, P.; Mukerjee, S.; et al. Identification of catalytic sites in cobalt-nitrogen-carbon materials for the oxygen reduction reaction. Nat. Commun. 2017, 8, 957. [CrossRef]

13. Wang, X.X.; Cullen, D.A.; Pan, Y.T.; Hwang, S.; Wang, M.; Feng, Z.; Wang, J.; Engelhard, M.H.; Zhang, H.; $\mathrm{He}, \mathrm{Y}$; et al. Nitrogen-coordinated single cobalt atom catalysts for oxygen reduction in proton exchange membrane fuel cells. Adv. Mater. 2018, 30, 1706758-1706768. [CrossRef] [PubMed]

14. Zhang, H.; Hwang, S.; Wang, M.; Feng, Z.; Karakalos, S.; Luo, L.; Qiao, Z.; Xie, X.; Wang, C.; Su, D.; et al. Single atomic iron catalysts for oxygen reduction in acidic media: Particle size control and thermal activation. J. Am. Chem. Soc. 2017, 139, 14143-14149. [CrossRef]

15. Zhu, C.; Shi, Q.; Xu, B.Z.; Fu, S.; Wan, G.; Yang, C.; Yao, S.; Song, J.; Zhou, H.; Du, D.; et al. Hierarchically Porous $\mathrm{M}-\mathrm{N}-\mathrm{C}(\mathrm{M}=\mathrm{Co}$ and $\mathrm{Fe})$ Single-atom electrocatalysts with robust $\mathrm{MN}_{\mathrm{x}}$ active moieties enable enhanced ORR performance. Adv. Energy Mater. 2018, 29, 1801956-1801963. [CrossRef]

16. Li, J.; Jaouen, F. Structure and activity of metal-centered coordination sites in pyrolyzed metal-nitrogen-carbon catalysts for the electrochemical reduction of $\mathrm{O}_{2}$. Curr. Opin. Electrochem. 2018, 9, 198-206. [CrossRef]

17. Li, J.; Ghoshal, S.; Liang, W.; Sougrati, M.-T.; Jaouen, F.; Halevi, B.; McKinney, S.; McCool, G.; Ma, C.; Yuan, X.; et al. Structural and mechanistic basis for the high activity of Fe-N-C catalysts toward oxygen reduction. Energy Environ. Sci. 2016, 9, 2418-2432. [CrossRef]

18. Jia, Q.; Ramaswamy, N.; Tylus, U.; Strickland, K.; Li, J.; Serov, A.; Artyushkova, K.; Atanassov, P.; Anibal, J.; Gumeci, C.; et al. Spectroscopic insights into the nature of active sites in iron-nitrogen-carbon electrocatalysts for oxygen reduction in acid. Nano Energy 2016, 29, 65-82. [CrossRef]

19. Jia, Q.; Ramaswamy, N.; Hafiz, H.; Tylus, U.; Strickland, K.; Wu, G.; Barbiellini, B.; Bansil, A.; Holby, E.F.; Zelenay, P.; et al. Experimental observation of redox-induced Fe-N switching behavior as a determinant role for oxygen reduction activity. ACS Nano 2015, 9, 12496-12505. [CrossRef]

20. Choi, C.H.; Lim, H.-K.; Chung, M.W.; Chon, G.; Sahraie, N.R.; Altin, A.; Sougrati, M.-T.; Stievano, L.; Oh, H.S.; Park, E.S.; et al. The Achilles' heel of iron-based catalysts during oxygen reduction in an acidic medium. Energy Environ. Sci. 2018, 11, 3176-3182. [CrossRef]

21. Jaouen, F.; Lefèvre, M.; Dodelet, J.-P.; Cai, M. Heat-treated Fe/N/C catalysts for $\mathrm{O}_{2}$ electroreduction: Are active sites hosted in micropores? J. Phys. Chem. B 2006, 110, 5553-5558. [CrossRef] [PubMed]

22. Proietti, E.; Jaouen, F.; Lefèvre, M.; Larouche, N.; Tian, J.; Herranz, J.; Dodelet, J.-P. Iron-based cathode catalyst with enhanced power density in polymer electrolyte membrane fuel cells. Nat. Commun. 2011, 2, 416. [CrossRef] [PubMed]

23. Shui, J.; Chen, C.; Grabstanowicz, L.; Zhao, D.; Liu, D.-J. Highly efficient nonprecious metal catalyst prepared with metal-organic framework in a continuous carbon nanofibrous network. Proc. Natl. Acad. Sci. USA 2015, 112, 10629-10634. [CrossRef] [PubMed]

24. Chang, Y.; Antonietti, M.; Fellinger, T.P. Synthesis of nanostructured carbon through ionothermal carbonization of common organic solvents and solutions. Angew. Chem. Int. Ed. 2015, 54, 5507-5512. [CrossRef] [PubMed]

25. Pampel, J.; Denton, C.; Fellinger, T.-P. Glucose derived ionothermal carbons with tailor-made porosity. Carbon 2016, 107, 288-296. [CrossRef]

26. Fellinger, T.-P. Sol-gel carbons from ionothermal syntheses. J. Sol-Gel Sci. Technol. 2017, 81, 52-58. [CrossRef]

27. Pampel, J.; Mehmood, A.; Antonietti, M.; Fellinger, T.-P. Ionothermal template transformations for preparation of tubular porous nitrogen doped carbons. Mater. Horizons 2017, 4, 493-501. [CrossRef]

28. Antonietti, M.; Fechler, N.; Fellinger, T.-P. Carbon aerogels and monoliths: Control of porosity and nanoarchitecture via sol-gel routes. Chem. Mater. 2013, 26, 196-210. [CrossRef]

29. Li, J.; Chen, S.; Li, W.; Wu, R.; Ibraheem, S.; Li, J.; Ding, W.; Li, L.; Wei, Z. A eutectic salt-assisted semi-closed pyrolysis route to fabricate high-density active-site hierarchically porous $\mathrm{Fe} / \mathrm{N} / \mathrm{C}$ catalysts for the oxygen reduction reaction. J. Mater. Chem. A 2018, 6, 15504-15509. [CrossRef]

30. Li, J.; Alsudairi, A.; Ma, Z.-F.; Mukerjee, S.; Jia, Q. Asymmetric volcano trend in oxygen reduction activity of Pt and non-Pt catalysts: In situ identification of the site-blocking effect. J. Am. Chem. Soc. 2017, 139, 1384-1387. [CrossRef] 
31. Webster, S.; Maultzsch, J.; Thomsen, C.; Liu, J.; Czerw, R.; Terrones, M.; Adar, F.; John, C.; Whitley, A.; Carroll, D.L. Raman characterization of nitrogen doped multiwalled carbon nanotubes. MRS Online Proc. Libr. Arch. 2003, 772. [CrossRef]

32. Ferrari, A.C.; Basko, D.M. Raman spectroscopy as a versatile tool for studying the properties of graphene. Nat. Nanotechnol. 2013, 8, 235-246. [CrossRef] [PubMed]

33. Wu, G.; Santandreu, A.; Kellogg, W.; Gupta, S.; Ogoke, O.; Zhang, H.; Wang, H.-L.; Dai, L. Carbon nanocomposite catalysts for oxygen reduction and evolution reactions: From nitrogen doping to transition-metal addition. Nano Energy 2016, 29, 83-110. [CrossRef]

34. Jiao, L.; Wan, G.; Zhang, R.; Zhou, H.; Yu, S.-H.; Jiang, H.-L. From Metal-organic frameworks to single-atom Fe implanted N-doped porous carbons: Efficient oxygen reduction in both alkaline and acidic media. Angew. Chem. Int. Ed. 2018, 130, 8661-8665. [CrossRef]

35. Chen, P.; Zhou, T.; Xing, L.; Xu, K.; Tong, Y.; Xie, H.; Zhang, L.; Yan, W.; Chu, W.; Wu, C.; et al. Atomically dispersed iron-nitrogen species as electrocatalysts for bifunctional oxygen evolution and reduction reactions. Angew. Chem. Int. Ed. 2017, 56, 610-614. [CrossRef] [PubMed]

36. Yi, J.-D.; Xu, R.; Wu, Q.; Zhang, T.; Zang, K.-T.; Luo, J.; Liang, Y.-L.; Huang, Y.-B.; Cao, R. Atomically dispersed iron-nitrogen active sites within porphyrinic triazine-based frameworks for oxygen reduction reaction in both alkaline and acidic media. ACS Energy Lett. 2018, 3, 883-889. [CrossRef]

37. Strickland, K.; Miner, E.; Jia, Q.; Tylus, U.; Ramaswamy, N.; Liang, W.; Sougrati, M.-T.; Jaouen, F.; Mukerjee, S. Highly active oxygen reduction non-platinum group metal electrocatalyst without direct metal-nitrogen coordination. Nat. Commun. 2015, 6, 7343. [CrossRef]

38. Tuček, J.; Zbořil, R.; Namai, A.; Ohkoshi, S.-I. $\varepsilon-\mathrm{Fe}_{2} \mathrm{O}_{3}$ : An advanced nanomaterial exhibiting giant coercive field, millimeter-wave ferromagnetic resonance, and magnetoelectric coupling. Chem. Mater. 2010, 22, 6483-6505. [CrossRef]

39. Kramm, U.I.; Herrmann-Geppert, I.; Behrends, J.; Lips, K.; Fiechter, S.; Bogdanoff, P. On an easy way to prepare metal-nitrogen doped carbon with exclusive presence of $\mathrm{MeN}_{4}$-type sites active for the ORR. J. Am. Chem. Soc. 2016, 138, 635-640. [CrossRef]

40. Chen, J.Y.; Dang, L.; Liang, H.; Bi, W.; Gerken, J.B.; Jin, S.; Alp, E.E.; Stahl, S.S. Operando analysis of NiFe and $\mathrm{Fe}$ oxyhydroxide electrocatalysts for water oxidation: Detection of $\mathrm{Fe}^{4+}$ by Mossbauer spectroscopy. J. Am. Chem. Soc. 2015, 137, 15090-15093. [CrossRef]

41. Zboril, R.; Mashlan, M.; Petridis, D. Iron (III) oxides from thermal processes synthesis, structural and magnetic properties, Mössbauer spectroscopy characterization, and applications. Chem. Mater. 2002, 14, 969-982. [CrossRef]

42. Kamali-M, S.; Ericsson, T.; Wäppling, R. Characterization of iron oxide nanoparticles by Mössbauer spectroscopy. Thin Solid Films 2006, 515, 721-723. [CrossRef]

43. Shinjo, T.; Kiyama, M.; Sugita, N.; Watanabe, K.; Takada, T. Surface magnetism of $\alpha-\mathrm{Fe}_{2} \mathrm{O}_{3}$ by Mössbauer spectroscopy. J. Magn. Magn. Mater. 1983, 35, 133-135. [CrossRef]

44. Sougrati, M.T.; Goellner, V.; Schuppert, A.K.; Stievano, L.; Jaouen, F. Probing active sites in iron-based catalysts for oxygen electro-reduction: A temperature-dependent ${ }^{57} \mathrm{Fe}$ Mössbauer spectroscopy study. Catal. Today 2016, 262, 110-120. [CrossRef]

45. Kramm, U.I.; Herranz, J.; Larouche, N.; Arruda, T.M.; Lefèvre, M.; Jaouen, F.; Bogdanoff, P.; Fiechter, S.; Abs-Wurmbach, I.; Mukerjee, S.; et al. Structure of the catalytic sites in Fe/N/C-catalysts for $\mathrm{O}_{2}$-reduction in PEM fuel cells. Phys. Chem. Chem. Phys. 2012, 14, 11673-11688. [CrossRef] [PubMed]

46. Liang, H.-W.; Wei, W.; Wu, Z.-S.; Feng, X.; Müllen, K. Mesoporous metal-nitrogen-doped carbon electrocatalysts for highly efficient oxygen reduction reaction. J. Am. Chem. Soc. 2013, 135, 16002-16005. [CrossRef] [PubMed]

47. Chung, H.T.; Cullen, D.A.; Higgins, D.; Sneed, B.T.; Holby, E.F.; More, K.L.; Zelenay, P. Direct atomic-level insight into the active sites of a high-performance PGM-free ORR catalyst. Science 2017, 357, 479-484. [CrossRef]

48. Li, Y.; Huang, J.; Hu, X.; Bi, L.; Cai, P.; Jia, J.; Chai, G.; Wei, S.; Dai, L.; Wen, Z. Fe vacancies induced surface $\mathrm{FeO}_{6}$ in nanoarchitectures of $\mathrm{N}$-doped graphene protected $\beta$-FeOOH: Effective active sites for $\mathrm{pH}$-universal electrocatalytic oxygen reduction. Adv. Funct. Mater. 2018, 28, 1803330-1803338. [CrossRef] 
49. Negro, E.; Nale, A.; Vezzù, K.; Pagot, G.; Polizzi, S.; Bertoncello, R.; Ansaldo, A.; Prato, M.; Bonaccorso, F.; Rutkowska, I.A.; et al. Hierarchical oxygen reduction reaction electrocatalysts based on $\mathrm{FeSn}_{0.5} \mathrm{species}$ embedded in carbon nitride-graphene based supports. Electrochim. Acta 2018, 280, 149-162. [CrossRef]

50. Negro, E.; Delpeuch, A.B.; Vezzu, K.; Nawn, G.; Bertasi, F.; Ansaldo, A.; Pellegrini, V.; Dembinska, B.; Zoladek, S.; Miecznikowski, K.; et al. Toward Pt-free anion-exchange membrane fuel cells: Fe-Sn carbon nitride-graphene core-shell electrocatalysts for the oxygen reduction reaction. Chem. Mater. 2018, 30, 2651-2659. [CrossRef]

51. Kong, F.; Fan, X.; Kong, A.; Zhou, Z.; Zhang, X.; Shan, Y. Covalent phenanthroline framework derived FeS@Fe ${ }_{3} \mathrm{C}$ composite nanoparticles embedding in N-S-codoped carbons as highly efficient trifunctional electrocatalysts. Adv. Funct. Mater. 2018, 28, 1803973. [CrossRef]

52. Fan, X.; Kong, F.; Kong, A.; Chen, A.; Zhou, Z.; Shan, Y. Covalent porphyrin framework-derived Fe 2 P@ $\mathrm{Fe}_{4} \mathrm{~N}$-coupled nanoparticles embedded in N-doped carbons as efficient trifunctional electrocatalysts. ACS Appl. Mater. Interfaces 2017, 9, 32840-32850. [CrossRef] [PubMed]

53. Varnell, J.A.; Edmund, C.; Schulz, C.E.; Fister, T.T.; Haasch, R.T.; Timoshenko, J.; Frenkel, A.I.; Gewirth, A.A. Identification of carbon-encapsulated iron nanoparticles as active species in non-precious metal oxygen reduction catalysts. Nat. Commun. 2016, 7, 12582. [CrossRef] [PubMed]

54. Reda, M.; Hansen, H.A.; Vegge, T. DFT Study of the oxygen reduction reaction on carbon-coated iron and iron carbide. ACS Catal. 2018, 8, 10521-10529. [CrossRef]

55. Ravel, B.; Newville, M. ATHENA, ARTEMIS, HEPHAESTUS: Data analysis for X-ray absorption spectroscopy using IFEFFIT. J. Synchrotron Radiat. 2005, 12, 537-541. [CrossRef] [PubMed]

(C) 2019 by the authors. Licensee MDPI, Basel, Switzerland. This article is an open access article distributed under the terms and conditions of the Creative Commons Attribution (CC BY) license (http:/ / creativecommons.org/licenses/by/4.0/). 